Sit)

\title{
Factors Affecting the Production of Sweet Potatoes in Semarang District
}

\author{
Trias Purnomo ${ }^{凶}$ \\ Jurusan Ekonomi Pembangunan, Fakultas Ekonomi, Universitas Negeri Semarang \\ Permalink/DOI: https://doi.org/10.15294/efficient.v2i1.3078o
}

Received: July 2018 ; Accepted: October 2018 ; Published: January 2019

\begin{abstract}
The purpose of this research is: 1) To know the description of sweet potato farming in Semarang regency in economic terms. 2) To know and analyze the influence of the factors of production (land area, labor, seeds, fertilizer) to production of sweet potato in Semarang regency. 3) To know and analyze the influence of all factors of production (land area, labor, seeds, fertilizer) together to production of sweet potato in Semarang Regency. This research type is descriptive research by using quantitative approach. Independent variables in this study are land area, labor, fertilizer and seedlings. While the dependent variable is the production of sweet potato. The method of analysis used in this research is multiple regression analysis with OLS (Ordinary Least Square) method. The results of this study indicate that the variable land area has a positive and significant influence with the coefficient of 0.67 . Labor variable has positive and significant influence with coefficient value of 0.28. While variable of fertilizer and seedlings do not have a significant influence on sweet potato production. Variable land area, labor, fertilizer and seedlings together have a significant influence on productivity of sweet potato in Semarang regency.
\end{abstract}

Keywords: Sweet Potatoes, Productivity, Influence, Labor, Semarang Regency

\begin{abstract}
Abstrak
Tujuan dari penelitian ini adalah: 1) Untuk mengetahui gambaran usahatani ubi jalar di Kabupaten Semarang secara ekonomi. 2) Untuk mengetahui dan menganalisis pengaruh faktor-faktor produksi (luas lahan, tenaga kerja, benih, pupuk) terhadap produksi ubi jalar di Kabupaten Semarang. 3) Untuk mengetahui dan menganalisis pengaruh semua faktor produksi (luas lahan, tenaga kerja, benih, pupuk) secara bersama-sama terhadap produksi ubi jalar di Kabupaten Semarang. Jenis penelitian ini adalah penelitian deskriptif dengan menggunakan pendekatan kuantitatif. Variabel independen dalam penelitian ini adalah luas lahan, tenaga kerja, pupuk dan bibit. Sedangkan variabel terikatnya adalah produksi ubi jalar. Metode analisis yang digunakan dalam penelitian ini adalah analisis regresi berganda dengan metode OLS (Ordinary Least Square). Hasil penelitian ini menunjukkan bahwa variabel luas lahan memiliki pengaruh positif dan signifikan dengan koefisien o,67. Variabel tenaga kerja memiliki pengaruh positif dan signifikan dengan nilai koefisien o,28. Sedangkan variabel pupuk dan bibit tidak memiliki pengaruh yang signifikan terhadap produksi ubi jalar. Variabel luas lahan, tenaga kerja, pupuk dan bibit secara bersama-sama memiliki pengaruh yang signifikan terhadap produktivitas ubi jalar di Kabupaten Semarang.
\end{abstract}

Kata Kunci: Ubi Jalar, Produktifitas, Pengaruh, Tenaga Kerja, Kabupaten Semarang

How to Cite: Purnomo, T. (2019). Factors Affecting the Production of Sweet Potatoes in Semarang District. EFFICIENT Indonesian Journal of Development Economics, 2(1), 282-289. https://doi.org/10.15294/efficient.v2i1.3078o

(C) 2019 Semarang State University. All rights reserved

\footnotetext{
Alamat Korespondensi :

Alamat: Gedung L2 Lantai 2 FE Unnes

Kampus Sekaran, Gunungpati, Semarang, 50229

E-mail : Triaspurnomo99@gmail.com
}

ISSN 2655-6197 


\section{INTRODUCTION}

The agricultural sector is one of the sectors that are the center of attention in national development, especially those relating to the management and utilization of strategic results, especially those concerning food commodities. The management and utilization of the results of agricultural products is expected to be carried out in a more planned manner with optimum utilization and can be enjoyed by the entire population of Indonesia. The policy strategy to develop the agricultural sector in Indonesia is important to be arranged as agriculture has various problems and needs a comprehensive policy (Setiawan A.B \& Prajanti S.D.W, 2016). The food agriculture sector is a sector that is generally cultivated by farmers in various regions in Indonesia.

Sweet potato is one of the third staple foods in Indonesia after rice and corn. Besides that, sweet potato has a cheaper price compared to rice and corn. In addition, sweet potatoes are also one of the commodities that have prospects to be developed again in order to meet the needs of domestic and international markets. Sweet potatoes can be developed into various kinds of processing, namely chips, jam, cosmetic ingredients and flour. In research conducted by (Prajanti, 2009) said that sweet potatoes can be processed into a variety of flour. The results of sweet potato flour are also not much different in quality from rice flour. Sweet potato production spreads to various provinces in Indonesia, one of which is in Central Java Province. According to the 2016 Agricultural Data and Information System Center, Central Java itself is included in the five biggest sweet potato producing provinces in Indonesia. Based on data from the Central Statistics Agency in 2017 the Province of Central Java has an area of sweet potato covering an area of
7,076 hectares, sweet potato production of 151,312 tons, and productivity of $213.84 \mathrm{kw} /$ ha. Sweet potato land area in Central Java province is divided into several regions. The following is a district with the 5 biggest sweet potato land area in Central Java province in 2012 - 2016 :

Table 1. 5 districts with the Land of Sweet Potato Biggest in Central Java province Years 2012-2016 (Ha)

\begin{tabular}{clccccc}
\hline No & Districts & 2012 & 2013 & 2014 & 2015 & 2016 \\
\hline 1 & Semarang & 964 & 970 & 1.186 & 981 & 981 \\
& & & & & & \\
2 & Magelang & 969 & 906 & 1.154 & 957 & 957 \\
3 & Karanganyar & 754 & 642 & 860 & 868 & 868 \\
4 & Wonosobo & 896 & 818 & 999 & 736 & 736 \\
& & & & & & \\
5 & Batang & 463 & 727 & 1.192 & 567 & 567 \\
\hline
\end{tabular}

Province, 2017), Data is processed

When viewed from data 1.1, Semarang Regency is the district that has the widest land area in Central Java. Although the area of sweet potato in Semarang Regency is wider than other regencies, including Karanganyar Regency, the production and productivity of sweet potatoes in Semarang Regency are always below Karanganyar Regency. In 2016, the area of sweet potato land in Karanganyar Regency covered 868 hectares with a production of 31,076 tons and productivity of 358.o1 kw / ha. While Semarang Regency in the same year with a larger land area of 981 hectares, but only able to produce a production of 24,812 tons and productivity of only $252.92 \mathrm{kw} / \mathrm{ha}$ (BPS, 2017). Semarang Regency has the potential to develop sweet potato cultivation, in addition to being supported by the size of the area, sweet potato 
cultivation in Semarang Regency is also production, and productivity of sweet potatoes supported by the condition of the area and the in Semarang Regency in 2012-2016 weather. The condition of land area, can be seen more clearly in Figure 1 below:

\begin{tabular}{|c|c|c|c|c|c|c|}
\hline \multirow{4}{*}{ 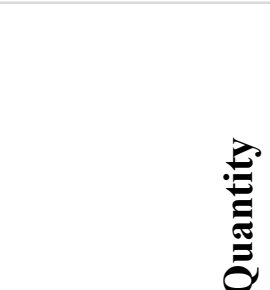 } & \multirow{4}{*}{$\begin{array}{r}3500 \\
3000 \\
2500 \\
2000 \\
1500 \\
1000 \\
500 \\
0\end{array}$} & \multicolumn{5}{|c|}{$\mathrm{C}^{2}$} \\
\hline & & \multicolumn{5}{|c|}{ 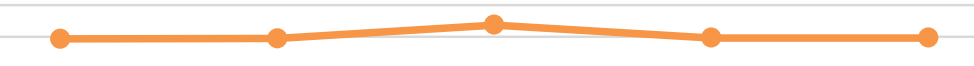 } \\
\hline & & \multicolumn{5}{|c|}{$\rightarrow$} \\
\hline & & 2012 & 2013 & 2014 & 2015 & 2016 \\
\hline \multicolumn{2}{|l|}{- Land Area (Ha) } & 964 & 970 & 1186 & 981 & 981 \\
\hline \multicolumn{2}{|c|}{$\longrightarrow$ Production (Tens of Tons) } & 3186.5 & 2454.6 & 2756.2 & 2481.1 & 2481.1 \\
\hline \multicolumn{2}{|c|}{ —Productivity (kw/Ha) } & 296.69 & 253.06 & 232.39 & 252.9 & 252.9 \\
\hline
\end{tabular}

Figure 1. Land Area, Production, and Productivity of Sweet Potatoes in Semarang Regency in 2012-2016

Source: Central Statistics Agency of Central Java Province 2017, data processed

Figure 1 above shows that the area ofsweet potato in Semarang Regency in 20122016 tends to increase by around $20-25 \%$. The significant increase in land area is due to the fact that many people are shifting from other commodity agriculture to sweet potato farming. This is because people think that sweet potato farming is relatively easier. However, the tendency of an increase in sweet potato land area in Semarang Regency was not followed by an increase in production. Sweet potato production in Semarang Regency in 2012-2016 tended to decrease, even though the production factors remained even some experienced an increase in one of them. While the productivity of sweet potatoes in Semarang Regency also decreased. Semarang Regency has 19 sub-districts that produce sweet potatoes. However, there are three regions with sweet potato production centers, namely Bergas, Sumowono and Bandungan Districts. The three regions produce sweet potatoes around $60-70 \%$ of all sweet potato production in Semarang Regency.

\section{RESEARCH METHOD}

This type of research is descriptive research using a quantitative approach. The data to be studied in this study consisted of data on land area, labor, fertilizer, seeds, and sweet potato production obtained from a sample of sweet potato farmers. In this study, the population is farmers who grow sweet potatoes on their land and rented land from owners in Semarang Regency. Because the population of the study is very broad and limited funds, energy and time to the author, so for the sample of this study selected areas with the largest land area and the largest production in the district of Semarang. The location of this study is in the districts of Bergas, Sumowono and Bandungan. The number of sweet potato farmers in the three sub-districts is 3.414 people. Determination of the number of samples taken is by using the 
Slovin Formula (Sugiyono, 2016). In Seeds $\left(\mathrm{X}_{4}\right)$. The method that will be used for accordance with research conducted by the analysis of this research is multiple Setiawan (2015), in this study in determining regression analysis with OLS (Ordinary Least the sample also uses the Slovin Formula. Here is the Slovin Formula:

$$
\mathrm{N}=\mathrm{N} /\left(\mathbf{1}+\mathrm{NE}^{\wedge} \mathbf{2}\right)
$$

Explanation :
$\mathrm{n} \quad=$ the number of samples in the study area
$\mathrm{N}=$ the number of population in the study area
$\mathrm{e} \quad=$ Fault tolerance limit $(10 \%)$

Based on the population to be studied and with a $10 \%$ error tolerance, the samples obtained were 97 sweet potato farmers in Bergas, Sumowono and Bandungan Districts. Variables used in this research: Dependent variable is the amount of sweet potato production produced by farmers in one planting period (Y), and the independent variables the same research as (Andriani, 2015) : land area $\left(\mathrm{X}_{1}\right)$, Labor $\left(\mathrm{X}_{2}\right)$, Fertilizer $\left(\mathrm{X}_{3}\right)$ and
Square) method. Multiple regression analysis is the method used to determine the magnitude of the effect of changes from an independent variable to the dependent variable (Gujarati, 2013).

\section{RESULTS AND DISCUSSION}

Sweet potato farming in Semarang Regency has production centers in three subdistricts, Bergas, Sumowono and Bandungan Districts. This farming is the main livelihood of the people in the area. The majority of farmers in the three sub-districts are aged 51-60 years. Sweet potato farming in Semarang Regency uses an average land area of 10,000-14,999 $\mathrm{m}^{2}$, with a workforce of 20-39 people, with the use of fertilizer $201-400 \mathrm{Kg}$, and the use of seeds as much as 1 - 5.000 stems. To see how much influence from land area, labor, seed fertilizer, to sweet potato production, the following is the result of processing with Eviews 9.o tools.

Tabel 2. Output Regression

\begin{tabular}{|c|c|c|c|c|}
\hline Variabel & Coeficient & Std. Error & T- Statistic & Probability \\
\hline $\mathrm{C}$ & 1.065141 & 0,427186 & 2,493386 & 0,0144 \\
\hline Ln_Land Area & 0,671804 & 0,088003 & 7,633913 & 0,0000 \\
\hline Ln_Labour & 0,282942 & 0,073963 & 3,825473 & 0,0002 \\
\hline Ln_Fertilizer & 0,129038 & 0,88375 & 1,460123 & 0,1477 \\
\hline Ln_Seeds & 0,067838 & 0,044023 & 1,540966 & 0,1268 \\
\hline R-Squared & 0,863319 & & Prob. Jarque Bera & 0,406230 \\
\hline Adjusted R- Squared & o,857376 & & $\begin{array}{l}\text { Prob. Obs* R- Squared } \\
\text { (LM-Test) }\end{array}$ & 0,2602 \\
\hline Durbin - Watson Stat & 1,450471 & & $\begin{array}{l}\text { Prob. Obs* R- Squared } \\
\text { (White) }\end{array}$ & 0,1664 \\
\hline F - Statistic & 145,2745 & & Prob. F Statistic & 0,0000 \\
\hline
\end{tabular}

Source : Outpout E- Views 9.o, 2018 
Based on the regression results above, the following econometric models are obtained:

$$
\begin{aligned}
\operatorname{LnY}= & \beta o+\beta_{1} \operatorname{LnX} 1+\beta_{2} \operatorname{LnX} 2+\beta_{3} \\
& \operatorname{LnX}_{3}+\beta_{4} \operatorname{LnX} 4+\mathrm{Ui}_{\ldots \ldots \ldots \ldots \ldots . . .(2)} \\
\text { LnProd }= & 1,06+0,67 \operatorname{LnLL}+0,28 \mathrm{LnTK}+ \\
& 0,13 \mathrm{LnPPK}+0,07 \mathrm{LnBBT}
\end{aligned}
$$

Based on the regression results obtained $\mathrm{R}^{2}$ value of 0.863 . This means that the ability of model variations of land area, labor, fertilizer and seedlings can explain sweet potato production in Semarang Regency well that is equal to $86.3 \%$, while the remaining $13,4 \%$ can be explained by other variables.

Based on the regression results, the land area variable has t-statistics> t-table that is equal to (7.633913> 2.62747) and the probability $<\alpha$ is equal to $(0.0000<0.05)$. From the test results it can be explained that the land area variable has a significant influence on sweet potato production in Semarang Regency. Labor variables have t-statistics> ttable that is equal to $(3.825473>2.62747)$ and the probability $<\alpha$ is equal to $(0.0000<0.05)$. From the test results it can be explained that labor variables have a significant effect on sweet potato production in Semarang Regency. Fertilizer variables have t-statistics $<$ t-table $(1,460123<2,62747)$. and the probability $\alpha$ is equal to (0.1477> 0.05). From the test results it can be explained that fertilizer does not have a real influence on sweet potato production in Semarang Regency. Seed variables have tstatistics $<$ t-table $(1.540966<2.62747)$. and the probability $>\alpha$ is equal to $(0.1268>0.05)$, so from the test results it can be explained that the seedlings do not have a significant effect on sweet potato production in Semarang Regency.

Statistical test $\mathrm{F}$ shows that whether all the independent variables included in the model have a joint effect on the dependent variable. The test method is by comparing Fcount with F-table. The calculated F / Fstatistic is 145.2745, while f-table with a significance level of $\alpha=5 \%, \mathrm{df} 1=5^{-1}=4$ and df $2=97-5=92$ then the value of Ftable $=2.47$ is obtained. With F-count greater than f-table, $\mathrm{Ho}$ is rejected and $\mathrm{Ha}$ is accepted. So simultaneously the variables of land area, labor, fertilizer and seeds have an influence on sweet potato production in Semarang Regency.

\section{Effect of Land Area on Sweet Potato Production}

Based on the regression results indicate that the land area has a coefficient of 0.67 , meaning that if the input of land area experiences an increase of $1 \%$, it will obtain a production increase of $0.67 \%$ with variable assumptions of labor, fertilizer and fixed seeds. Based on the regression results, the land area variable has t-statistics $>\mathrm{t}$-table that is equal to (7.633913 $>2.62747)$ and the probability $<\alpha$ is equal to $(0.0000<0.05)$. Then Ho is rejected and Ha is accepted. From the test results it can be explained that the land area variable has a positive influence on sweet potato production and the correlation is in accordance with the hypothesis and statistically significant. So it can be concluded that the land area has a significant influence on sweet potato production in Semarang Regency.

The results of the estimation of this study are in accordance with the hypothesis that land area has a positive influence on sweet 
potato production in Semarang Regency, thus means that if the more extensive land owned by farmers, the more yam production will be produced. Farmers who have more extensive land will get more crops. This is because by having a large land, farmers can use it to grow crops with more capacity, so it is not impossible to produce more sweet potato production. This research is in line with research (Prabowo, 2014), which states that the land area variable has a positive and significant influence on the production of sugar cane.

\section{Effect of Labor on Sweet Potato Production}

Based on the results of the labor regression has a coefficient of 0.28 , so that it can be explained that if the labor input has increased by $1 \%$, it will be obtained an increase in production of $0.28 \%$ with the assumption of variable land area, fertilizer and seeds remain. While based on the results of the regression variable labor has t-statistics> t-table that is equal to (3.825473> 2.62747) and the probability $<\alpha$ is equal to $(0.0000<0.05)$. Then Ho is rejected and Ha is accepted. From the test results it can be explained that the labor variable has a positive influence on sweet potato production and the correlation is in accordance with the hypothesis and statistically significant. So it can be concluded that labor has a significant influence on sweet potato production in Semarang Regency. The results of this study are consistent with the hypothesis that labor has a positive influence on sweet potato production in Semarang
Regency. Thus if the workforce used by farmers more and more it will produce more and more production. With the increase in labor, it will make farming activities more quickly carried out, with the implementation of all activities in farming, it will encourage the production of production. However, the addition of the workforce must also be balanced with the amount of land area. This research is in line with research (Yuliani, 2006), which states that labor variable has a positive and significant influence on the production of rice.

\section{Effect of Fertilizer on Sweet Potato Production}

Based on the results of fertilizer regression has a coefficient of 0.13 , so it can be explained that if the fertilizer input has increased by $1 \%$, it will be obtained an increase in production of $0.13 \%$ with the assumption of variable land area, labor and fixed seeds. Whereas, based on the results of variable regression, fertilizer has a t-statistic <t-table that is $(1,460123<2,62747)$ and the probability $\alpha$ is equal to (0.1477> 0.05), then Ho is accepted and Ha is rejected. From the test results it can be explained that fertilizer has a positive influence on sweet potato production and the correlation is not in accordance with the hypothesis and is not statistically significant. It can be concluded that fertilizer does not have a real effect on sweet potato production in Semarang Regency. The estimation results of this study are not in 
accordance with the hypothesis which states that fertilizer has a positive influence on sweet potato production. This is caused by the lack of fertilizer availability so that farmers use makeshift fertilizer, so it cannot support increased sweet potato production. This research is in line with research (Rahayu, 2010), which states the variable of fertilizer used in farm have a positive effect but not significant on soybean production in Sukoharjo Regency.

\section{Effect of Seedlings on Sweet Potato Production}

Based on the regression results, the seedlings have a coefficient of 0.07 , so that it can be explained that if the seed input experiences an addition of 15 , there will be a production increase of $0.07 \%$ with the assumption that the land area, labor and fertilizer variables are fixed. Whereas based on the regression results, the seed variable has a tstatistic <t-table that is $(1.540966<2.62747)$. and the probability $>\alpha$ is equal to (o.1268> 0.05), then Ho is accepted and Ha is rejected. So it can be concluded that the seedlings do not have a significant effect on sweet potato production in Semarang Regency. The results of the estimation of this study are not in accordance with the hypothesis that the seeds have a positive influence on sweet potato production. This is due to the fact that the use of many seeds does not necessarily produce a lot of production. Based on the implementation in the field, seed selection is the main factor in increasing sweet potato production. If wrong in choosing seeds, it will cause a decrease in production or not optimal production. Therefore, what causes seedlings does not significantly affect sweet potato production, ie farmers who use seedlings from the stems of the plants they cut from the plants they have before and then used as new seeds. This is due to the lack of availability of sweet potato seeds in the market. So that the seeds owned by farmers cannot be ascertained that the seeds are not superior seeds. So that the seed factor does not have a significant effect on sweet potato production in Semarang Regency. This research is not in line with the research (Sari, 2015), which states that seed variables that have a positive and significant influence on sweet potato production in Dolo, Sigi District. Because the use of seeds on sweet potato farming in Semarang Regency is different from other regions.

\section{Effect of land area, Labor, Fertilizer and Seedlings simultaneously on Sweet Potato Production}

Based on the results of the regression found the results of $f$ count of 145.2745 , while $f$ table with a significance level of $\alpha=5 \%, \mathrm{df}_{1}=$ $5^{-1}=4$ and $\mathrm{df}_{2}=97-5=92$ then the value of Ftable $=2.47$ was obtained. With F-count greater than f-table, Ho is rejected and $\mathrm{Ha}$ is accepted. So together the variables of land area, labor, fertilizer and seedlings have an influence on sweet potato production in Semarang Regency.

\section{CONCLUSION}

Based on research conducted on the analysis of sweet potato production farming in Semarang Regency, the following conclusions can be drawn; Sweet potato farming in Semarang Regency has production centers in three sub- districts namely Bergas, Sumowono 
and Bandungan Districts. This farming is the main livelihood of the people in the area. The majority of farmers in the three sub-districts are aged $51-60$ years. Sweet potato farming in Semarang Regency uses an average land area of 10,000-14,999 $\mathrm{m}^{2}$, with a workforce of 20-39 people, with the use of fertilizer $201-400 \mathrm{Kg}$, and the use of seeds as much as $1-5,000$ stems.

Factors of production of land area and labor have a significant effect on sweet potato production in Semarang Regency with a confidence level of $95 \%$, with land area factor being the factor that has the highest influence on sweet potato production in Semarang Regency. While the factors of fertilizer and seed production do not have a significant effect on sweet potato production in Semarang Regency. Factors of production of land area, labor, fertilizer and seeds together have an influence on sweet potato production in Semarang Regency.

\section{REFERENCES}

Andriani, M. d. (2015). Analisis Faktor-faktor yang Mempengaruhi Produksi Ubi Jalar di Kecamatan Kayu Aro Kabupaten Kerinci. Jurnal Sosio Ekonomika Bisnis Vol 18 No. 2.

Badan Pusat Statistik. 2017. Tenaga kerja Indonesia. Website: https://bps.go.id./ (diakses tanggal 7 Januari 2018).

Badan Pusat Statistik. 2017. Produksi Ubi Jalar di Jawa Tengah. Website: https://bps.go.id./ (diakses tanggal 7 Januari 2018).

Badan Pusat Statistik. 2017. Produksi Ubi Jalar di Kabupaten Semarang. Website: https://bps.go.id./ (diakses tanggal 7 Januari 2018).

Balai Penyuluhan Pertanian Kecamatan Bandungan. 2017. Jumlah Petani Ubi Jalar per desa di Kecamatan Bergas. Kabupaten Semarang: Badan Pelaksan Penyluhan Kabupaten Semarang.

Balai Penyuluhan Pertanian Kecamatan Bergas. 2017. Jumlah Petani Ubi Jalar per desa di Kecamatan Bergas. Kabupaten Semarang: Badan Pelaksan Penyluhan Kabupaten Semarang.
Balai Penyuluhan Pertanian Kecamatan Sumowono. 2017. Jumlah Petani Ubi Jalar per desa di Kecamatan Bergas. Kabupaten Semarang: Badan Pelaksan Penyluhan Kabupaten Semarang.

Gujarati, Damodar. 2013. Dasar-Dasar Ekonometrika. Jakarta: Salemba Empat.

Prabowo, A. S. (2014). Analisis Faktor-faktor yang Mempengaruhi Produksi Gula di Jawa Tengah Tahun 2004-2013. EDAJ Vol 3 No. 3.

Prajanti, Sucihatiningsih Dian Wisika, et all. 2009. "Analisis Persepsi dan Preferensi Ibu Rumah Tangga terhadap Produk Pangan Olahan Berbasis Tepung Ubi Jalar dalam Meningkatkan Keanekaragaman Pangan”. JEJAK, Vol. 2 No. 1 Hal 8o-9o. Semarang : Universitas Negeri semarang.

Pusat Data dan Sistem Informasi Pertanian. 2016. Ekspor Ubi Jalar Indonesia. Website: https://pusdatin.setjen.pertanina.go.id/ (diakses pada tanggal 22 Maret 2018).

Rahayu, W. d. (2010). Analisis Efisiensi Ekonomi Penggunaan Faktor-faktor Produksi pada Usahatani Kedelai di Kabupaten Sukoharjo. Caraka Tani XXV No. 1.

Sari, R. D. (2015). Analisis Produksi Ubi Jalar di Desa Pulu, Kecamatan Dolo Selatan, Kabupaten Sigi. Jurnal Agroland Vol 22 No. 3, 265-271.

Setiawan, Avi Budi dan Prasetyo Ari Bowo. 2015. "Technical, Allocative, and Economic Efficiencies of Rice Cultivation”. Dalam JEJAK Vol 8 No. 2 Hal 149-159. Semarang: Universitas Negeri Semarang.

Sistem Informasi Harga dan Produksi Komoditi Jawa Tengah. 2017. Harga Komoditas Bahan Makanan Pokok di Kabupaten Semarang tahun 2016-2017. Website : http://hargajateng.org (diakses pada tanggal 27 Maret 2018).

Sugiyono. (2016). Metode Penelitian Kuantitatif, Kualitatif dan R\&D. Bandung: ALFABETA.

Sukirno, Sadono. 2005. Teori Pengantar Mikro Ekonomi. Jakarta: PT Raja Grafindo.

Yuliani, Z. d. (2006). Pengaruh Penggunaan Faktor-faktor Produksi terhadap Produksi Sawah di Kecamatan Lambuya, Kabupaten Konawe. Semarang: Universitas Diponegoro.

Setiawan, A.B. \& Prajanti, SDW. (2016). Strategies To Develop Food Crop Commodity To Improve The Prosperity Of Rural Farmers In Grobogan District. Journal of Indonesian Applied Economics, Universitas Brawijaya, Vol. 6. No. 2 (2016). DOI: http://dx.doi.org/10.21776/ub.jiae.2016.oo6.o2. 